\title{
BMJ Open Examining the association between serum lactic dehydrogenase and all-cause mortality in patients with metabolic syndrome: a retrospective observational study
}

\author{
Li-Wei Wu, ${ }^{1,2,3,4}$ Tung-Wei Kao, ${ }^{1,2,3}$ Chien-Ming Lin, ${ }^{4}$ Hui-Fang Yang, ${ }^{1,2}$ \\ Yu-Shan Sun, ${ }^{1,2}$ Fang-Yih Liaw, ${ }^{1,2,3,4}$ Chung-Ching Wang, ${ }^{1,2}$ Tao-Chun Peng, ${ }^{1,2}$ \\ Wei-Liang Chen ${ }^{1,2,3,4}$
}

To cite: Wu L-W, Kao T-W, Lin C-M, et al. Examining the association between serum lactic dehydrogenase and all-cause mortality in patients with metabolic syndrome: a retrospective observational study. BMJ Open 2016;6: e011186. doi:10.1136/ bmjopen-2016-011186

- Prepublication history for this paper is available online. To view these files please visit the journal online (http://dx.doi.org/10.1136/ bmjopen-2016-011186).

Received 18 January 2016 Revised 15 March 2016 Accepted 5 May 2016

CrossMark

For numbered affiliations see end of article.

Correspondence to Dr Wei-Liang Chen; weiliang0508@gmail.com

\section{ABSTRACT}

Objectives: Emerging evidence indicates that elevated serum lactic dehydrogenase (LDH) levels are associated with increased cardiovascular mortality, but the mechanisms for this relationship remain uncertain. Since metabolic syndrome (MetS) is correlated with a higher risk of cardiovascular complications, we investigated the joint association between serum LDH levels and all-cause mortality in the US general population with MetS.

Design: Retrospective study.

Setting: The USA.

Participants: A retrospective observational study of 3872 adults with MetS and 7516 adults without MetS in the National Health and Nutrition Examination Survey III was performed.

Main outcome measures: Participants with and without MetS were both divided into 3 groups according to their serum LDH level. Multivariable Cox regression analyses and Kaplan-Meier survival probabilities were used to jointly relate all-cause, cardiovascular and cancer mortality risk to different serum LDH levels.

Results: For all-cause mortality in participants with MetS, multivariable adjusted HRs were $1.006(95 \% \mathrm{Cl}$ 0.837 to $1.210 ; p=0.947$ ) for serum LDH of $149-$ $176 \mathrm{U} / \mathrm{L}$ compared with $65-149 \mathrm{U} / \mathrm{L}$, and 1.273 (95\% Cl 1.049 to $1.547 ; p=0.015)$ for serum LDH of $176-$ $668 \mathrm{U} / \mathrm{L}$ compared with 65-149 U/L.

Conclusions: Results support a positive association between higher level of serum LDH and mortality from all causes in individuals with MetS.

\section{INTRODUCTION}

Lactate dehydrogenase (LDH), a cytoplasmic enzyme in most tissues and organs, catalyses the interconversion of pyruvate, which is the final product of glycolysis, to lactate with

\section{Strengths and limitations of this study}

- The study used the nationwide population-based data set.

- The study explored the impact of serum lactate dehydrogenase (LDH) levels on all-cause mortality in the US general population with metabolic syndrome.

- Serum LDH levels were collected at only one point during the follow-up period.

accompanying interconversion of NADH and $\mathrm{NAD}^{+}$. Abnormal extracellular appearance of $\mathrm{LDH}$, which is detectable in the serum and used for detection of cell or tissue damage, was reported as an ominous outcome marker in a large number of clinical conditions, ${ }^{1-4}$ including severe infection and sepsis, malignancies, acute myocardial infarction, and liver diseases such as cirrhosis and metastatic carcinoma of the liver. In addition, abnormal high levels of serum LDH have also been demonstrated to correlate with cardiovascular mortality of long-term arsenic exposure. ${ }^{5}$

Metabolic syndrome (MetS), which is an integrated concept that asserts that a common cluster of disorders including abdominal obesity, impaired fasting glucose, elevated blood pressures (BPs) and dyslipidaemia, are predictive for type 2 diabetes and atherosclerotic diseases. ${ }^{6}$ In the third National Health and Nutrition Examination Survey III (NHANES III), MetS prevalence in US adults increased with age and was highly prevalent. ${ }^{7}$ It is generally accepted that MetS is composed of several risk factors for cardiovascular complications. Lakka et al have demonstrated that cardiovascular and allcause mortality in Finnish men with MetS 
was significantly increased. Similar findings were reported in a previous study of NHANES II. ${ }^{9}$ However, few studies have addressed the association between allcause mortality in MetS and the level of serum LDH. This prompts us to investigate the correlation between serum LDH and all-cause mortality risk in individuals with MetS using the NHANES III data.

\section{MATERIALS AND METHODS}

\section{Study population}

We selected adults with MetS aged between 20 and 59 years in the NHANES III study, which represented a multistage stratified investigation of the US population living in households during 1988-1994. ${ }^{10}$ Demographic information was collected through a structured home interview and accompanied by a series of physical examination and blood sampling at a mobile examination centre. The NHANES III study was executed in accordance with the Declaration of Helsinki and approved by the National Center for Health Statistics (NCHS) Institutional Review Board after obtaining the written informed consent of participants before starting the study.

\section{Definition of MetS}

MetS, which included $\geq 3$ of the following components, was based on the revised National Cholesterol Education Program's Adult Treatment Panel III. ${ }^{11}$ MetS was diagnosed at baseline for all the adult participants. The first component of MetS was raised waist circumference, which was defined by waist circumference $>102 \mathrm{~cm}$ in men and $>88 \mathrm{~cm}$ in women. The second component of MetS was elevated BP, which was defined by systolic $\mathrm{BP} \geq 130 \mathrm{~mm} \mathrm{Hg}$ or diastolic $\mathrm{BP} \geq 85 \mathrm{~mm} \mathrm{Hg}$. The third component of MetS was elevated serum fasting glucose, which was defined by serum fasting glucose $\geq 100 \mathrm{mg} / \mathrm{dL}$ $(5.6 \mathrm{mmol} / \mathrm{L})$. The fourth component of MetS was raised serum triglycerides (TGs), which was defined by serum TGs $\geq 150 \mathrm{mg} / \mathrm{dL}(1.7 \mathrm{mmol} / \mathrm{L})$. The fifth component of MetS was reduced serum high-density lipoprotein cholesterol (HDL-C), which was defined by $\mathrm{HDL}-\mathrm{C}<40 \mathrm{mg} / \mathrm{dL} \quad(1.03 \mathrm{mmol} / \mathrm{L})$ for men and $<50 \mathrm{mg} / \mathrm{dL}(1.3 \mathrm{mmol} / \mathrm{L})$ for women.

\section{Definition of LDH tertiles group}

Serum LDH was measured at baseline for all the adult participants. We determined the LDH tertiles of study groups with MetS and chose 65-149, 149-176 and 176$668 \mathrm{U} / \mathrm{L}$ as the cut-off value for grouping. Patients were then divided into three groups (highest, middle and lowest, below and above cut-off level, respectively).

\section{Follow-up data on all-cause mortality}

The NHANES III study also contained detailed mortality information and follow-up data from the time of study participation. The follow-up data on all-cause mortality, NHANES III Linked Mortality File, were provided by the NCHS according to the probabilistic matching between
National Death Index death certificate records and NHANES III participants. The follow-up data on allcause mortality of the NHANES III study were from 1988 to $2006 .^{12}$

\section{Exclusion criteria of participants}

Among these populations, eligible participants with incomplete data for the serum $\mathrm{LDH}$ measurement, household interview, or laboratory and clinical examinations were excluded. Moreover, in order to minimise the confounding effect, we excluded participants with liver disease (level of serum aspartate aminotransferase (AST) or alanine aminotransaminase $>40 \mathrm{U} / \mathrm{L}$ ) or bone disease (level of serum alkaline phosphatase $>117 \mathrm{U}$ ) at baseline.

\section{Data analysis}

All statistical procedures and analyses were implemented using SPSS V.18 (SPSS, Inc, Chicago, Illinois, USA). The analytic data were executed by the complex samples procedure to incorporate sampling weights and prevent incorrect estimates of variance. Quantitative parameters were indicated as the values of mean and SD, while qualitative data were presented as the values of number and percentage. Demographic characteristics were compared using the independent t-test or Wilcoxon rank-sum test for continuous variables and the $\chi^{2}$ test for discrete variables. Two-sided $\mathrm{p}$ values of $<0.05$ were considered to indicate significance. Binary logistic regression analysis was performed for the predictive factors of all-cause mortality. Survival analysis was performed to examine the association of serum LDH with all-cause, cardiovascular and cancer mortality. Kaplan-Meier survival curves were plotted to ascertain the relationship of serum LDH in participants with MetS and subsequent mortality. Associations between serum LDH tertiles and end points were evaluated in multivariable Cox proportional hazard models. Covariates adjustment was performed by an extended model approach: Model 1 was not adjusted for other variables; model 2 was further adjusted for age, race, sex and body mass index; model $3=$ model 2+serum $\mathrm{C}$ reactive protein (CRP), serum total bilirubin, serum creatinine, serum aspartate transaminase, serum uric acid, smoking, cardiovascular disease (CVD), cancer.

\section{RESULTS}

The study population consisted of 3872 adults with MetS and 7516 adults without MetS in the NHANES III database with serum LDH levels. The clinical characteristics of the study population by serum LDH tertiles are summarised in table 1. Participants in the MetS group with higher tertiles of serum LDH levels were inclined to have higher age, higher systolic and diastolic BP, higher waist circumference, higher serum HDL-C level, higher serum uric acid level and higher serum AST level. Participants in the MetS group with higher serum LDH 
Table 1 Characteristics of study participants with and without MetS

\begin{tabular}{|c|c|c|c|c|c|c|c|c|c|c|}
\hline \multirow[b]{3}{*}{ Characteristic } & \multicolumn{5}{|l|}{ MetS group } & \multicolumn{5}{|l|}{ Non-MetS group } \\
\hline & \multicolumn{3}{|c|}{ Tertiles of serum LDH levels (U/L) } & \multirow[b]{2}{*}{ Total $n=3872$} & \multirow[b]{2}{*}{$\begin{array}{l}p \\
\text { Value }\end{array}$} & \multicolumn{3}{|c|}{ Tertiles of serum LDH levels (U/L) } & \multirow[b]{2}{*}{ Total $\mathrm{n}=7516$} & \multirow[b]{2}{*}{$\begin{array}{l}\mathbf{p} \\
\text { Value } \\
\end{array}$} \\
\hline & $\begin{array}{l}\text { 65-149 (U/L) } \\
n=1279\end{array}$ & $\begin{array}{l}149-176(U / L) \\
n=1316\end{array}$ & $\begin{array}{l}176-668(U / L) \\
n=1277\end{array}$ & & & $\begin{array}{l}\text { 36-138 (U/L) } \\
\mathrm{n}=2522\end{array}$ & $\begin{array}{l}138-163(U / L) \\
n=2487\end{array}$ & $\begin{array}{l}163-454(U / L) \\
n=2507\end{array}$ & & \\
\hline \multicolumn{11}{|l|}{ Continuous variables } \\
\hline $\begin{array}{l}\text { Serum LDH, mean } \\
\text { (SD) }\end{array}$ & $131.12(15.10)$ & $162.96(7.56)$ & $203.92(30.69)$ & $165.96(35.84)$ & $<0.001$ & $121.41(13.82)$ & $150.41(7.22)$ & $188.65(24.48)$ & $153.43(32.28)$ & $<0.001$ \\
\hline $\begin{array}{l}\text { Age (years), mean } \\
\text { (SD) }\end{array}$ & $51.93(17.66)$ & $56.34(17.83)$ & $58.61(17.96)$ & $55.63(18.03)$ & $<0.001$ & $38.09(15.40)$ & $41.85(16.99)$ & $46.75(18.91)$ & $42.22(17.52)$ & $<0.001$ \\
\hline $\begin{array}{l}\text { Systolic blood } \\
\text { pressure, mean (SD) }\end{array}$ & $132.12(20.70)$ & $136.79(22.05)$ & $141.59(23.93)$ & $136.86(22.60)$ & $<0.001$ & $114.14(15.03)$ & $117.65(17.20)$ & $121.81(20.02)$ & $117.86(17.81)$ & $<0.001$ \\
\hline $\begin{array}{l}\text { Diastolic blood } \\
\text { pressure, mean (SD) }\end{array}$ & $75.21(13.12)$ & $76.25(12.79)$ & $76.69(14.94)$ & $76.06(13.66)$ & 0.022 & $68.49(12.14)$ & $70.64(11.43)$ & $71.09(13.02)$ & $70.07(12.27)$ & $<0.001$ \\
\hline $\begin{array}{l}\text { Waist circumference } \\
(\mathrm{cm}) \text {, mean (SD) }\end{array}$ & $101.16(12.23)$ & $102.77(12.73)$ & $102.78(13.32)$ & $102.24(12.79)$ & 0.001 & $85.26(11.57)$ & $87.22(11.99)$ & $89.63(12.53)$ & $87.37(12.17)$ & $<0.001$ \\
\hline $\begin{array}{l}\text { Serum triglycerides } \\
(\mathrm{mg} / \mathrm{dL}) \text {, mean }(\mathrm{SD})\end{array}$ & $156.33(114.58)$ & $155.77(117.28)$ & $150.40(110.12)$ & $154.18(114.07)$ & 0.349 & $124.08(105.63)$ & $128.45(94.37)$ & $133.70(90.53)$ & $128.73(97.14)$ & 0.002 \\
\hline $\begin{array}{l}\text { Serum HDL-C (mg/ } \\
\mathrm{dL}) \text {, mean (SD) }\end{array}$ & $44.93(14.73)$ & $45.82(13.56)$ & $48.61(15.03)$ & $46.45(14.53)$ & $<0.001$ & $53.46(14.21)$ & $53.72(14.69)$ & $54.99(15.66)$ & $54.06(14.88)$ & 0.001 \\
\hline $\begin{array}{l}\text { Serum glucose, mean } \\
\text { (SD) }\end{array}$ & $112.41(47.24)$ & $113.16(46.89)$ & $108.28(35.24)$ & $111.30(43.56)$ & 0.009 & $89.15(20.11)$ & $90.59(19.46)$ & 92.27 (21.13) & $90.67(20.28)$ & $<0.001$ \\
\hline $\begin{array}{l}\text { Serum CRP, mean } \\
\text { (SD) }\end{array}$ & $0.56(0.83)$ & $0.54(0.74)$ & $0.55(0.76)$ & $0.55(0.77)$ & 0.717 & $0.38(0.79)$ & $0.34(0.41)$ & $0.40(0.64)$ & $0.37(0.63)$ & 0.005 \\
\hline $\begin{array}{l}\text { Serum uric acid, } \\
\text { mean (SD) }\end{array}$ & $5.43(1.46)$ & $5.69(1.52)$ & $5.69(1.54)$ & $5.60(1.51)$ & $<0.001$ & $4.87(1.34)$ & $5.10(1.35)$ & $5.34(1.48)$ & $5.10(1.41)$ & $<0.001$ \\
\hline AST (U/L), mean (SD) & $17.95(4.95)$ & $19.56(5.33)$ & $21.13(5.34)$ & $19.55(5.37)$ & $<0.001$ & $17.82(4.58)$ & $19.44(4.91)$ & $21.87(5.62)$ & $19.71(5.32)$ & $<0.001$ \\
\hline $\begin{array}{l}\text { Serum total bilirubin, } \\
\text { mean (SD) }\end{array}$ & $0.55(0.28)$ & $0.55(0.25)$ & $0.55(0.26)$ & $0.55(0.26)$ & 0.821 & $0.50(0.35)$ & $0.60(0.30)$ & $0.61(0.33)$ & $0.60(0.33)$ & 0.679 \\
\hline \multicolumn{11}{|l|}{ Categorical variables } \\
\hline Male, $\mathrm{n}(\%)$ & $548(42.8)$ & $541(41.1)$ & $452(35.4)$ & $1541(39.8)$ & $<0.001$ & $1134(45.0)$ & $1261(50.7)$ & $1257(50.1)$ & $3652(48.6)$ & $<0.001$ \\
\hline $\begin{array}{l}\text { Non-Hispanic white, } \mathrm{n} \\
(\%)\end{array}$ & $581(45.4)$ & $652(49.5)$ & $553(43.3)$ & $1786(46.1)$ & $<0.001$ & $1122(44.5)$ & $1117(44.9)$ & $1029(41.0)$ & $3268(43.5)$ & $<0.001$ \\
\hline $\begin{array}{l}\text { Diabetes mellitus, } n \\
(\%)\end{array}$ & $188(14.7)$ & $178(13.5)$ & $148(11.6)$ & $514(13.3)$ & 0.161 & 48 (1.9) & $66(2.7)$ & $89(3.6)$ & $203(2.7)$ & 0.001 \\
\hline Malignancy, n (\%) & $46(3.6)$ & $70(5.3)$ & $61(4.8)$ & $177(4.6)$ & 0.158 & $56(2.2)$ & $80(3.2)$ & $91(3.6)$ & $227(3.0)$ & 0.011 \\
\hline Stroke, n (\%) & $36(2.8)$ & $56(4.3)$ & $65(5.1)$ & $157(4.1)$ & 0.047 & $20(0.8)$ & $31(1.2)$ & $50(2.0)$ & $101(1.3)$ & 0.001 \\
\hline $\begin{array}{l}\text { Congestive heart } \\
\text { failure, } n(\%)\end{array}$ & $41(3.2)$ & $68(5.2)$ & $63(4.9)$ & $172(4.4)$ & 0.101 & $41(1.6)$ & $45(1.8)$ & $63(2.5)$ & $149(2.0)$ & 0.051 \\
\hline Smoker, n (\%) & $176(13.8)$ & $190(14.4)$ & $134(10.5)$ & $500(12.9)$ & 0.006 & $246(9.8)$ & $270(10.9)$ & $240(9.6)$ & $756(10.1)$ & 0.264 \\
\hline
\end{tabular}


levels were less likely to be ever-smokers. The univariate comparisons between patients with MetS and non-MetS with and without death are shown in table 2. The unadjusted associations of serum LDH tertiles with mortality in participants with MetS are shown in figure 1. Higher serum LDH level had lower cumulative survival in those with MetS. The predictive factors of all-cause mortality according to binary logistic regression analysis (shown in table 3) were the serum LDH (OR 1.005, 95\% CI 1.003 to 1.007 ), age (OR 1.114, 95\% CI 1.106 to 1.122), systolic BP (OR 1.036, 95\% CI 1.032 to 1.039), serum TG (OR 1.002, 95\% CI 1.001 to 1.002 ), serum HDL-C (OR 1.005, 95\% CI 1.000 to 1.009), serum glucose (OR 1.008, 95\% CI 1.007 to 1.010 ), waist circumference (OR $0.999,95 \%$ CI 0.994 to 1.004 ) and serum CRP (OR 1.121, 95\% CI 1.032 to 1.219 ).

For all-cause mortality in paticipants with MetS (shown in table 4), the unadjusted HRs of mode 1 for each tertiles of increasing serum LDH were 1.205 (95\% CI 1.007 to 1.441 ; $\mathrm{p}=0.041$ ) for serum $\mathrm{LDH}$ of $149-176 \mathrm{U} / \mathrm{L}$ compared with $65-149 \mathrm{U} / \mathrm{L}$, and 1.572 (95\% CI 1.315 to 1.881; $\mathrm{p}<0.001$ ) for serum LDH of $176-668 \mathrm{U} / \mathrm{L}$ compared with $65-149 \mathrm{U} / \mathrm{L}$, respectively. The multivariable adjusted HRs of mode 2 for each tertiles of increasing serum LDH were 0.980 (95\% CI 0.819 to 1.174 ; $\mathrm{p}=0.827$ ) for serum LDH of $149-176 \mathrm{U} / \mathrm{L}$ compared

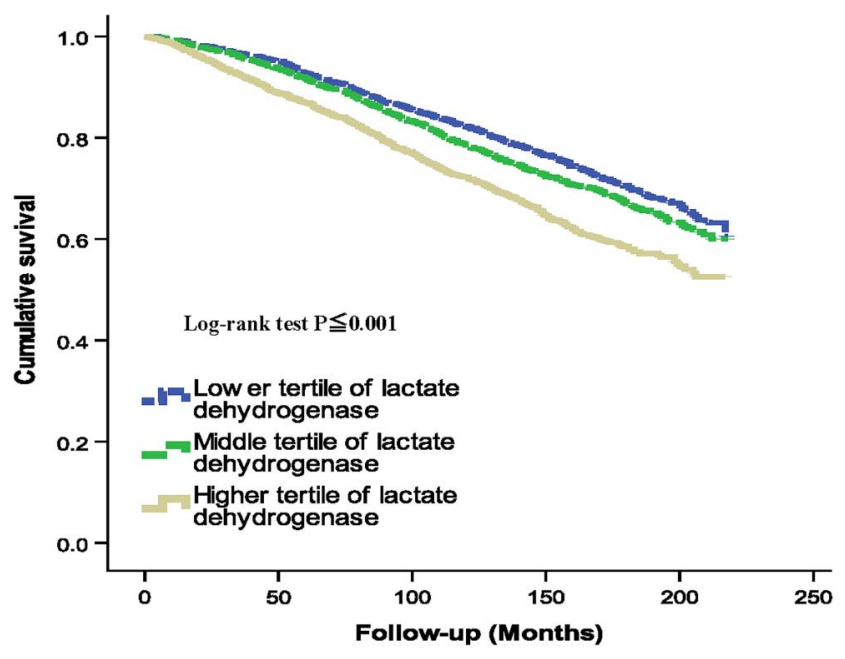

Figure 1 Kaplan-Meier plot of association of serum lactate dehydrogenase tertiles with mortality in participants with metabolic syndrome.

with $65-149 \mathrm{U} / \mathrm{L}$, and 1.220 (95\% CI 1.017 to 1.463 ; $\mathrm{p}=0.033$ ) for serum LDH of $176-668 \mathrm{U} / \mathrm{L}$ compared with 65-149 U/L, respectively. The multivariable adjusted HRs of mode 3 for each tertiles of increasing serum $\mathrm{LDH}$ were $1.006 \quad(95 \%$ CI 0.837 to 1.210 ;

Table 2 Univariate comparisons between patients with MetS and non-MetS with and without death

\begin{tabular}{|c|c|c|c|c|c|c|}
\hline \multirow[b]{2}{*}{ Characteristic } & \multicolumn{3}{|l|}{ MetS group } & \multicolumn{3}{|c|}{ Non-MetS group } \\
\hline & $\begin{array}{l}\text { Alive group } \\
\text { Total } n=2574\end{array}$ & $\begin{array}{l}\text { Death group } \\
\text { Total } n=1298\end{array}$ & p Value & $\begin{array}{l}\text { Alive group } \\
\text { Total } n=6401\end{array}$ & $\begin{array}{l}\text { Death group } \\
\text { Total } n=1115\end{array}$ & p Value \\
\hline \multicolumn{7}{|l|}{ Continuous variables } \\
\hline Serum LDH, mean (SD) & $163.93(33.70)$ & $169.95(39.47)$ & $<0.001$ & $151.74(31.51)$ & $163.01(34.86)$ & $<0.001$ \\
\hline Age (years), mean (SD) & $48.01(15.43)$ & 70.75 (12.38) & $<0.001$ & 38.14 (14.09) & $65.70(16.83)$ & $<0.001$ \\
\hline $\begin{array}{l}\text { Systolic blood pressure, mean } \\
\text { (SD) }\end{array}$ & $131.36(20.35)$ & $147.70(22.88)$ & $<0.001$ & $115.25(14.91)$ & $133.01(24.51)$ & $<0.001$ \\
\hline $\begin{array}{l}\text { Diastolic blood pressure, mean } \\
\text { (SD) }\end{array}$ & $76.90(13.10)$ & $74.38(14.55)$ & $<0.001$ & $6991(11.66)$ & $70.96(15.31)$ & 0.009 \\
\hline $\begin{array}{l}\text { Waist circumference }(\mathrm{cm}) \text {, mean } \\
\text { (SD) }\end{array}$ & $102.31(13.07)$ & $102.12(12.22)$ & 0.669 & $86.73(12.14)$ & $90.94(11.67)$ & $<0.001$ \\
\hline $\begin{array}{l}\text { Serum triglycerides }(\mathrm{mg} / \mathrm{dL}) \text {, mean } \\
\text { (SD) }\end{array}$ & $146.95(110.36)$ & $168.66(119.85)$ & $<0.001$ & $125.01(97.35)$ & $149.98(93.15)$ & $<0.001$ \\
\hline Serum HDL-C (mg/dL), mean (SD) & $46.12(14.25)$ & $47.11(15.06)$ & 0.045 & $54.09(14.64)$ & $53.86(16.21)$ & 0.626 \\
\hline Serum glucose, mean (SD) & $106.01(35.48)$ & $121.83(54.77)$ & $<0.001$ & $89.43(16.46)$ & 97.75 (34.08) & $<0.001$ \\
\hline Serum CRP, mean (SD) & $0.52(0.72)$ & $0.60(0.86)$ & 0.006 & $0.35(0.59)$ & $0.48(0.83)$ & $<0.001$ \\
\hline Serum uric acid, mean (SD) & $5.45(1.44)$ & $5.91(1.59)$ & $<0.001$ & $5.01(1.37)$ & $5.59(1.53)$ & $<0.001$ \\
\hline AST (U/L), mean (SD) & $19.48(5.39)$ & $19.68(5.32)$ & 0.286 & $19.62(5.32)$ & $20.21(5.33)$ & 0.001 \\
\hline Serum total bilirubin, mean (SD) & $0.54(0.26)$ & $0.58(0.27)$ & $<0.001$ & $0.60(0.33)$ & $0.59(0.31)$ & 0.276 \\
\hline \multicolumn{7}{|l|}{ Categorical variables } \\
\hline Male, n (\%) & $904(35.1)$ & $637(49.1)$ & $<0.001$ & 2935 (45.9) & $714(64.0)$ & $<0.001$ \\
\hline Non-Hispanic white, n (\%) & 985 (38.3) & $800(61.6)$ & $<0.001$ & $2604(40.7)$ & $662(59.4)$ & $<0.001$ \\
\hline Diabetes mellitus, n (\%) & $237(9.2)$ & 277 (21.3) & $<0.001$ & $121(1.9)$ & $81(7.3)$ & $<0.001$ \\
\hline Malignancy, n (\%) & $66(2.6)$ & $111(8.6)$ & $<0.001$ & $124(1.9)$ & $103(9.2)$ & $<0.001$ \\
\hline Stroke, n (\%) & $36(1.4)$ & $121(9.3)$ & $<0.001$ & $35(0.5)$ & $66(5.9)$ & $<0.001$ \\
\hline Congestive heart failure, $n(\%)$ & $63(2.4)$ & $109(8.4)$ & $<0.001$ & $55(0.9)$ & $94(8.4)$ & $<0.001$ \\
\hline Smoker, n (\%) & $247(9.6)$ & $253(19.5)$ & $<0.001$ & $532(8.3)$ & $224(20.1)$ & $<0.001$ \\
\hline
\end{tabular}


Table 3 Binary logistic regression analysis for the predictive factors of all-cause mortality in patients with metabolic syndrome

\begin{tabular}{|c|c|c|c|}
\hline Variable & OR & $95 \% \mathrm{Cl}$ & p Value \\
\hline Serum LDH & 1.005 & 1.003 to 1.007 & $<0.0001$ \\
\hline Age & 1.114 & 1.106 to 1.122 & $<0.0001$ \\
\hline SBP & 1.036 & 1.032 to 1.039 & $<0.0001$ \\
\hline Serum TG & 1.002 & 1.001 to 1.002 & $<0.0001$ \\
\hline Serum HDL-C & 1.005 & 1.000 to 1.009 & 0.045 \\
\hline Serum glucose & 1.008 & 1.007 to 1.010 & $<0.0001$ \\
\hline Waist circumference & 0.999 & 0.994 to 1.004 & 0.669 \\
\hline Serum CRP & 1.121 & 1.032 to 1.219 & 0.007 \\
\hline
\end{tabular}

$\mathrm{p}=0.947)$ for serum $\mathrm{LDH}$ of $149-176 \mathrm{U} / \mathrm{L}$ compared with $65-149 \mathrm{U} / \mathrm{L}$, and 1.273 (95\% CI 1.049 to 1.547 ; $\mathrm{p}=0.015$ ) for serum $\mathrm{LDH}$ of $176-668 \mathrm{U} / \mathrm{L}$ compared with $65-149 \mathrm{U} / \mathrm{L}$.

For cardiovascular mortality in participants with MetS (shown in table 5), the unadjusted HRs of mode 1 for each tertiles of increasing serum LDH were $1.394(95 \%$ CI 1.054 to $1.842 ; \mathrm{p}=0.020$ ) for serum $\mathrm{LDH}$ of $149-$ $176 \mathrm{U} / \mathrm{L}$ compared with 65-149 U/L, and $1.897(95 \%$ CI 1.440 to 2.499 ; $\mathrm{p}<0.001)$ for serum $\mathrm{LDH}$ of $176-$ $668 \mathrm{U} / \mathrm{L}$ compared with $65-149 \mathrm{U} / \mathrm{L}$, respectively. The multivariable adjusted HRs of mode 2 for each tertiles of increasing serum LDH were 1.061 (95\% CI 0.802 to 1.405; $\mathrm{p}=0.678$ ) for serum $\mathrm{LDH}$ of $149-176 \mathrm{U} / \mathrm{L}$ compared with 65-149 U/L, and 1.339 (95\% CI 1.010 to 1.775 ; $\mathrm{p}=0.042$ ) for serum $\mathrm{LDH}$ of $176-668 \mathrm{U} / \mathrm{L}$ compared with 65-149 U/L, respectively. The multivariable adjusted HRs of mode 3 for each tertiles of increasing serum LDH were $1.044 \quad(95 \%$ CI 0.783 to 1.393 ; $\mathrm{p}=0.769)$ for serum $\mathrm{LDH}$ of $149-176 \mathrm{U} / \mathrm{L}$ compared with $65-149 \mathrm{U} / \mathrm{L}$, and 1.280 (95\% CI 0.944 to 1.734 ; $\mathrm{p}=0.112)$ for serum $\mathrm{LDH}$ of $176-668 \mathrm{U} / \mathrm{L}$ compared with 65-149 U/L.
For cancer mortality in participants with MetS (shown in table 6), the unadjusted HRs (HRs) of mode 1 for each tertiles of increasing serum LDH were $0.844(95 \%$ CI 0.593 to $1.200 ; \mathrm{p}=0.345)$ for serum $\mathrm{LDH}$ of 149 $176 \mathrm{U} / \mathrm{L}$ compared with 65-149 U/L, and $1.294(95 \%$ CI 0.939 to $1.784 ; \mathrm{p}=0.115)$ for serum $\mathrm{LDH}$ of 176 $668 \mathrm{U} / \mathrm{L}$ compared with 65-149 U/L, respectively. The multivariable adjusted HRs of mode 2 for each tertiles of increasing serum LDH were 0.649 (95\% CI 0.455 to 0.926 ; $\mathrm{p}=0.017$ ) for serum $\mathrm{LDH}$ of $149-176 \mathrm{U} / \mathrm{L}$ compared with 65-149 U/L, and $1.029(95 \%$ CI 0.740 to 1.430; $\mathrm{p}=0.867$ ) for serum $\mathrm{LDH}$ of $176-668 \mathrm{U} / \mathrm{L}$ compared with 65-149 U/L, respectively. The multivariable adjusted HRs of mode 3 for each tertiles of increasing serum LDH were $0.725 \quad(95 \%$ CI 0.502 to 1.048 ; $\mathrm{p}=0.087$ ) for serum $\mathrm{LDH}$ of 149-176 U/L compared with $65-149 \mathrm{U} / \mathrm{L}$, and 1.221 (95\% CI 0.852 to 1.751 ; $\mathrm{p}=0.277$ ) for serum $\mathrm{LDH}$ of $176-668 \mathrm{U} / \mathrm{L}$ compared with 65-149 U/L.

\section{DISCUSSION}

Some prior studies have reported that serum $\mathrm{LDH}$ is a distinguishing clinical biomarker of severe underlying diseases, including solid and haematological malignancies, sepsis and severe infections. ${ }^{13}$ Moreover, several inflammatory diseases were also correlated with serum LDH. Recent research has highlighted the correlation between serum LDH levels and the long-term effect of chronic arsenic exposure on CVD. ${ }^{5}$ However, the link between serum LDH levels and all-cause mortality in patients with MetS has not been comprehensively evaluated. In this study, we examined the hypothesis that the relationship of serum $\mathrm{LDH}$ with all-cause mortality can be explained by the associations of both of these factors with MetS. Most notably, this is the first study, to the best of our knowledge, to demonstrate the relationship between serum LDH and all-cause mortality in the US population with MetS. We found that the link of serum $\mathrm{LDH}$ with mortality in participants with MetS persisted after various strategies for multiple covariates

Table 4 Cox proportional hazards regression of all-cause mortality for serum LDH in those with and without MetS

\begin{tabular}{|c|c|c|c|c|c|c|}
\hline \multirow[b]{2}{*}{ Models* } & \multicolumn{3}{|l|}{ MetS } & \multicolumn{3}{|l|}{ Non-MetS } \\
\hline & $\begin{array}{l}\text { Serum LDH } \\
\text { level tertiles }\end{array}$ & HR $(95 \% \mathrm{Cl})$ & p Value & $\begin{array}{l}\text { Serum LDH } \\
\text { level tertiles }\end{array}$ & HR (95\% Cl) & p Value \\
\hline \multirow[t]{2}{*}{ Model 1} & T2 vs T1 & $1.205(1.007$ to 1.441$)$ & 0.041 & T2 vs T1 & 1.557 (1.286 to 1.886$)$ & $<0.001$ \\
\hline & T3 vs T1 & $1.572(1.315$ to 1.881$)$ & $<0.001$ & T3 vs T1 & 2.133 (1.774 to 2.564$)$ & $<0.001$ \\
\hline \multirow[t]{2}{*}{ Model 2} & $\mathrm{~T} 2$ vs $\mathrm{T} 1$ & $0.980(0.819$ to 1.174$)$ & 0.827 & $\mathrm{~T} 2$ vs $\mathrm{T} 1$ & $1.122(0.925$ to 1.361$)$ & 0.242 \\
\hline & T3 vs T1 & $1.220(1.017$ to 1.463$)$ & 0.033 & T3 vs T1 & $1.070(0.884$ to 1.295$)$ & 0.486 \\
\hline \multirow[t]{2}{*}{ Model 3} & $\mathrm{~T} 2$ vs T1 & $1.006(0.837$ to 1.210$)$ & 0.947 & T2 vs T1 & $1.191(0.980$ to 1.448$)$ & 0.079 \\
\hline & T3 vs T1 & 1.273 (1.049 to 1.547$)$ & 0.015 & T3 vs T1 & $1.213(0.992$ to 1.484$)$ & 0.060 \\
\hline
\end{tabular}

${ }^{*}$ Adjusted covariates.

Model 1=unadjusted.

Model 2=adjustment for age, race, sex and BMI.

Model 3=model 2+serum CRP, serum total bilirubin, serum creatinine, serum aspartate transaminase, serum uric acid, smoking, CVD, cancer. $\mathrm{BMI}$, body mass index; CRP, C reactive protein; CVD, cardiovascular disease; LDH, lactate dehydrogenase; MetS, metabolic syndrome. 
Table 5 Cox proportional hazards regression of cardiovascular mortality for serum LDH in those with and without MetS

\begin{tabular}{|c|c|c|c|c|c|c|}
\hline \multirow[b]{2}{*}{ Models* } & \multicolumn{3}{|l|}{ MetS } & \multicolumn{3}{|l|}{ Non-MetS } \\
\hline & $\begin{array}{l}\text { Serum LDH } \\
\text { level tertiles }\end{array}$ & HR (95\% Cl) & $p$ Value & $\begin{array}{l}\text { Serum LDH } \\
\text { level tertiles }\end{array}$ & HR (95\% Cl) & p Value \\
\hline \multirow[t]{2}{*}{ Model 1} & T2 vs T1 & 1.394 (1.054 to 1.842$)$ & 0.020 & T2 vs T1 & 1.687 (1.230 to 2.314$)$ & 0.001 \\
\hline & T3 vs T1 & 1.897 (1.440 to 2.499$)$ & $<0.001$ & T3 vs T1 & 2.801 (2.084 to 3.765$)$ & $<0.001$ \\
\hline \multirow[t]{2}{*}{ Model 2} & $\mathrm{~T} 2$ vs $\mathrm{T} 1$ & 1.061 (0.802 to 1.405$)$ & 0.678 & $\mathrm{~T} 2$ vs $\mathrm{T} 1$ & 1.256 (0.915 to 1.724$)$ & 0.159 \\
\hline & T3 vs T1 & 1.339 (1.010 to 1.775$)$ & 0.042 & T3 vs T1 & 1.155 (0.851 to 1.566$)$ & 0.355 \\
\hline \multirow[t]{2}{*}{ Model 3} & $\mathrm{~T} 2$ vs $\mathrm{T} 1$ & 1.044 (0.783 to 1.393$)$ & 0.769 & $\mathrm{~T} 2$ vs $\mathrm{T} 1$ & 1.153 (0.836 to 1.591$)$ & 0.385 \\
\hline & T3 vs T1 & $1.280(0.944$ to 1.734$)$ & 0.112 & T3 vs T1 & 1.195 (0.865 to 1.651$)$ & 0.280 \\
\hline
\end{tabular}

${ }^{*}$ Adjusted covariates.

Model $1=$ unadjusted.

Model 2=adjustment for age, race, sex and BMI.

Model $3=$ model 2+serum CRP, serum total bilirubin, serum creatinine, serum aspartate transaminase, serum uric acid, smoking, CVD, cancer.

$\mathrm{BMI}$, body mass index; CRP, C reactive protein; CVD, cardiovascular disease; LDH, lactate dehydrogenase; MetS, metabolic syndrome.

adjustment. These findings confirmed that the association of serum LDH level with mortality was observed in patients with MetS, with 19\% higher hazard for all-cause mortality.

Systemic inflammatory indicators, including serum levels of CRP and LDH, may be a useful clinical prognostic indicator for survival and predicts the response for management in patients with specific disease. In a prior study of 213 patients with diffuse large B cell lymphoma receiving chemotherapy, high serum LDH level and systemic inflammation score were poor prognostic factors for overall survival. ${ }^{14}$ Moreover, Castelli et al ${ }^{15}$ found that in elderly individuals with pulmonary embolism, serum LDH level was a good predictor of short-term mortality due to the applicability and simpleness for routine use based on common clinical practice. In a recently published study conducted by Okur et $a l^{16}{ }^{16}$ concerning the clinical and laboratory features of those with respiratory failure and pneumonia caused by H1N1 influenza A virus, mortality was demonstrated to be significantly associated with an elevated serum LDH level. Similar inter-relations were observed from overall survival in patients with metastatic renal cell carcinoma, ${ }^{17}$ diagnosis of acute respiratory distress syndrome in the population at risk, ${ }^{18}$ early mortality in peritonitis-induced sepsis $^{19}$ and mortality in postinfarction myocardial rupture. ${ }^{20}$ These findings tend to indicate that serum LDH has significant prognostic value for clinical practice and our results strongly confirm another potential prediction of mortality in patients with MetS.

A variety of factors were associated with increased risk of MetS, including obesity, a sedentary lifestyle, insulin resistance and consumption of soft drinks. ${ }^{21}$ MetS was a condition of chronic low-grade inflammation as a consequence of complex interplay between genetic and environmental factors. ${ }^{22}$ Inflammation might be another potential explanation for the associations of elevated serum LDH with mortality in those with MetS. Several prior studies showed a clear and strong relationship between elevated levels of CRP and increased components of MetS, which linked with a greater chance of future CVD events. ${ }^{22} 23$ Furthermore, it had been showed that CRP levels may represent as an independent predictor for poor clinical outcomes in MetS. ${ }^{23}$ The paper in Drent $e t a l^{4}$ provided the latent utility of serum $\mathrm{LDH}$ as an inflammation biomarker in a large number of pulmonary diseases. There was a moderate positive correlation between CRP and LDH isoenzymes in those with chronic inflammatory disease, such as chronic obstructive pulmonary disease. ${ }^{25}$ These observations

Table 6 Cox proportional hazards regression of cancer mortality for serum LDH in those with and without MetS

\begin{tabular}{|c|c|c|c|c|c|c|}
\hline \multirow[b]{2}{*}{ Models* } & \multicolumn{3}{|l|}{ MetS } & \multicolumn{3}{|l|}{ Non-MetS } \\
\hline & $\begin{array}{l}\text { Serum LDH } \\
\text { level tertiles }\end{array}$ & HR (95\% Cl) & $\mathrm{p}$ Value & $\begin{array}{l}\text { Serum LDH } \\
\text { level tertiles }\end{array}$ & HR (95\% Cl) & p Value \\
\hline \multirow[t]{2}{*}{ Model 1} & $\mathrm{~T} 2$ vs $\mathrm{T} 1$ & 0.844 (0.593 to 1.200$)$ & 0.345 & $\mathrm{~T} 2$ vs $\mathrm{T} 1$ & 1.464 (1.032 to 2.075$)$ & 0.032 \\
\hline & T3 vs T1 & 1.294 (0.939 to 1.784$)$ & 0.115 & T3 vs T1 & 1.860 (1.328 to 2.606$)$ & $<0.001$ \\
\hline \multirow[t]{2}{*}{ Model 2} & T2 vs T1 & 0.649 (0.455 to 0.926$)$ & 0.017 & T2 vs T1 & 1.119 (0.787 to 1.589$)$ & 0.531 \\
\hline & T3 vs T1 & 1.029 (0.740 to 1.430$)$ & 0.867 & T3 vs T1 & 0.847 (0.595 to 1.205$)$ & 0.357 \\
\hline \multirow[t]{2}{*}{ Model 3} & $\mathrm{~T} 2$ vs T1 & 0.725 (0.502 to 1.048$)$ & 0.087 & $\mathrm{~T} 2$ vs T1 & 1.169 (0.818 to 1.671$)$ & 0.392 \\
\hline & T3 vs T1 & 1.221 (0.852 to 1.751$)$ & 0.277 & T3 vs $\mathrm{T} 1$ & $1.067(0.731$ to 1.556$)$ & 0.738 \\
\hline
\end{tabular}

${ }^{*}$ Adjusted covariates.

Model $1=$ unadjusted.

Model 2=adjustment for age, race, sex and BMI.

Model 3=model 2+serum CRP, serum total bilirubin, serum creatinine, serum aspartate transaminase, serum uric acid, smoking, CVD, cancer.

$\mathrm{BMI}$, body mass index; CRP, C reactive protein; CVD, cardiovascular disease; LDH, lactate dehydrogenase; MetS, metabolic syndrome. 
provided strong evidence that serum LDH was closely associated with inflammation. In our study, LDH may be as a systemic inflammatory marker and the association of mortality with serum LDH remained significant after statistical adjustment for CRP. Our results provide that the persistence of the serum $\mathrm{LDH}$-mortality relationship after multiple covariates adjustment indicates that serum LDH can be viewed as a significant clinical biomarker that is positively associated with increased mortality in patients with MetS.

However, there were several potential limitations in this study. First, serum LDH was collected at only one point during the follow-up period, which contributed to the biased results. Second, our study was a retrospective, observational analysis of an existing database that limited causal inferences. Third, residual confounding due to unmeasured confounders of the associations of serum LDH with mortality cannot be ruled out. Finally, owing to the unavailable isoforms of $\mathrm{LDH}$, we failed to draw inferences on whether the diversity of LDH was associated with increased survival or mortality.

In conclusion, the results of this study signify that in the US general population with MetS, higher serum LDH levels substantially increased the risk of all-cause mortality. Further studies should therefore determine the molecular mechanism of the causal pathways involved in the correlation of elevated serum LDH levels with mortality.

\section{Author affiliations}

${ }^{1}$ Division of Family Medicine, Department of Family and Community Medicine, Tri-Service General Hospital, Taipei, Taiwan (ROC)

${ }^{2}$ School of Medicine, National Defense Medical Center, Taipei, Taiwan (ROC)

${ }^{3}$ Division of Geriatric Medicine, Department of Family and Community

Medicine, Tri-Service General Hospital, Taipei, Taiwan (ROC)

${ }^{4}$ Graduate Institute of Medical Sciences, National Defense Medical Center,

Taipei, Taiwan (ROC)

Contributors L-WW contributed to the design of the study and to the initial data analysis and interpretation. He was responsible for the management and retrieval of data and also drafted the initial manuscript. L-WW and W-LC were also responsible for the data analysis decisions. W-LC conceptualised and designed the study, supervised all aspects of the study, critically reviewed and revised the manuscript, and approved the final manuscript as submitted. All authors meet the ICMJE criteria for authorship.

Funding This research received no specific grant from any funding agency in the public, commercial or not-for-profit sectors.

Competing interests None declared.

Provenance and peer review Not commissioned; externally peer reviewed.

Data sharing statement The data are available at the NHANES website (http:// www.cdc.gov/nchs/nhanes.htm).

Open Access This is an Open Access article distributed in accordance with the Creative Commons Attribution Non Commercial (CC BY-NC 4.0) license, which permits others to distribute, remix, adapt, build upon this work noncommercially, and license their derivative works on different terms, provided the original work is properly cited and the use is non-commercial. See: http:// creativecommons.org/licenses/by-nc/4.0/

\section{REFERENCES}

1. Cobben NA, Drent M, Schols AM, et al. Serum lactate dehydrogenase and its isoenzyme pattern in ex-coalminers. Respir Med 1997;91:616-23.
2. Glick JH Jr. Serum lactate dehydrogenase isoenzyme and total lactate dehydrogenase values in health and disease, and clinical evaluation of these tests by means of discriminant analysis. $A m \mathrm{~J}$ Clin Pathol 1969:52:320-8.

3. Matusiewicz SP, Williamson IJ, Sime PJ, et al. Plasma lactate dehydrogenase: a marker of disease activity in cryptogenic fibrosing alveolitis and extrinsic allergic alveolitis. Eur Respir $J$ 1993;6:1282-6.

4. Moss DW, Henderson AR. Enzymes. In: Burtis CA, Ashwood ER, eds. Tietz textbook of clinical chemistry. 2nd edn. Philadelphia: W. B. Saunders, 1986:735-896.

5. Liao YT, Chen CJ, Li WF, et al. Elevated lactate dehydrogenase activity and increased cardiovascular mortality in the arsenic-endemic areas of southwestern Taiwan. Toxicol Appl Pharmacol 2012;262:232-7.

6. Hackam DG, Anand SS. Emerging risk factors for atherosclerotic vascular disease: a critical review of the evidence. JAMA 2003;290:932-40.

7. Ford ES, Giles WH, Dietz WH. Prevalence of the metabolic syndrome among US adults: findings from the third National Health and Nutrition Examination Survey. JAMA 2002;287:356-9.

8. Lakka HM, Laaksonen DE, Lakka TA, et al. The metabolic syndrome and total and cardiovascular disease mortality in middle-aged men. JAMA 2002;288:2709-16.

9. Malik S, Wong ND, Franklin SS, et al. Impact of the metabolic syndrome on mortality from coronary heart disease, cardiovascular disease, and all causes in United States adults. Circulation 2004;110:1245-50.

10. Hyattsville, National Center for Health Statistics. Plan and operation of the Third National Health and Nutrition Examination Survey, 1988-94. Series 1: programs and collection procedures. Vital Health Stat 1 1994;32:1-407.

11. Grundy SM, Cleeman JI, Daniels SR, et al. Diagnosis and management of the metabolic syndrome: an American Heart Association/National Heart, Lung, and Blood Institute Scientific Statement. Circulation 2005;112:2735-52

12. Hyattsville. The Third National Health and Nutrition Examination Survey (NHANES III) Linked Mortality File, Mortality follow-up through 2006: Matching Methodology. 2009. (accessed 21 May 2014).

13. Huijgen HJ, Sanders GT, Koster RW, et al. The clinical value of lactate dehydrogenase in serum: a quantitative review. Eur $\mathrm{J}$ Clin Chem Clin Biochem 1997;35:569-79.

14. Jung $\mathrm{SH}$, Yang $\mathrm{DH}, \mathrm{Ahn}$ JS, et al. Serum lactate dehydrogenase with a systemic inflammation score is useful for predicting response and survival in patients with newly diagnosed diffuse large B-Cell lymphoma. Acta Haematol 2014;133:10-17.

15. Castelli R, Bucciarelli $\mathrm{P}$, Porro $\mathrm{F}$, et al. Pulmonary embolism in elderly patients: prognostic impact of the Cumulative Illness Rating Scale (CIRS) on short-term mortality. Thromb Res 2014;134:326-30.

16. Okur M, Erbey $F$, Yazicioglu $\mathrm{O}$, et al. $\mathrm{H} 1 \mathrm{~N} 1$ influenza $A$ virus related pneumonia and respiratory failure. Indian J Virol 2013;24:85-9.

17. Cetin B, Afsar B, Deger SM, et al. Association between hemoglobin, calcium, and lactate dehydrogenase variability and mortality among metastatic renal cell carcinoma. Int Urol Nephrol 2014;46:1081-7.

18. Terpstra ML, Aman J, van Nieuw Amerongen GP, et al. Plasma biomarkers for acute respiratory distress syndrome: a systematic review and meta-analysis. Crit Care Med 2014;2:691-700.

19. Liao MH, Chen SJ, Tsao CM, et al. Possible biomarkers of early mortality in peritonitis-induced sepsis rats. J Surg Res 2013;183:362-70

20. Yuan SM, Jing $\mathrm{H}$, Lavee J. The implications of serum enzymes and coagulation activities in postinfarction myocardial. Rev Bras Cir Cardiovasc 2011;26:7-14.

21. Dhingra R, Sullivan L, Jacques PF, et al. Soft drink consumption and risk of developing cardiometabolic risk factors and the metabolic syndrome in middle-aged adults in the community. Circulation 2007;116:480-8.

22. Kaur J. A comprehensive review on metabolic syndrome. Cardiol Res Pract 2014;2014:943162.

23. Clearfield MB. C-reactive protein: a new risk assessment tool for cardiovascular disease. J Am Osteopath Assoc 2005;105:409-16.

24. Drent M, Cobben NA, Henderson RF, et al. Usefulness of lactate dehydrogenase and its isoenzymes as indicators of lung damage or inflammation. Eur Respir J 1996;9:1736-42.

25. Nillawar AN, Bardapurkar JS, Bardapurkar SJ. High sensitive C-reactive protein as a systemic inflammatory marker and LDH-3 isoenzyme in chronic obstructive pulmonary disease. Lung India 2012;29:24-9. 